\title{
Studi deskriptif minat sosial pada remaja ditinjau dari latar belakang keluarga
}

p-ISSN 2746-8976; e-ISSN 2685-8428 ejournal.umm.ac.id/index.php/cognicia 2021, Vol 9(1):45-52 DOI:10.22219/cognicia.v9i1.14222 (c)The Author(s) 2021

(c)(1) $\$$.0 International license

\author{
Hultia Manani Syarqi ${ }^{1}$ dan Sofa Amalia ${ }^{1}$
}

\begin{abstract}
Today's teenagers spend more time with technology than interacting with people around them whereas adolescents should experience the process of learning and exploring and developing themselves through their surroundings and social environment to foster social interests. The purpose of this study is to describe the social interest of adolescents, especially regarding the family background using quantitative and qualitative approaches. The number of subjects in this study was 196 people with the criteria of the age is those in the age of 12-18 years. Data collection is conducted using the Social Interest Index (SII) instrument by Greever with a total of 32 items. The results of the study show that adolescents have moderate level social interest. There is no significant difference between social interest and the characteristics of the subjects or their family backgrounds.
\end{abstract}

\section{Keywords}

Social interests, adolescents, family background

\section{Pendahuluan}

Masa remaja merupakan periode transisi dari masa anakanak dengan masa dewasa dalam rentang kehidupan manusia (Santrock, 2012). Pertumbuhan dan perkembangan di masa remaja tidak lepas dari interaksi antara faktor-faktor genetik yang diturunkan orang tua, lingkungan, dan sosial yang berkaitan dengan keluarga, sekolah, teman bermain, dan lingkungan masyarakat umum.

Menurut Hurlock (2012) remaja pada tahap perkembangan ini memiliki kemampuan untuk (1) mencapai pola hubungan baru yang lebih matang dengan teman sebaya yang berbeda jenis kelamin sesuai dengan keyakinan dan etika moral yang berlaku di masyarakat, (2) mencapai peranan sosial sesuai dengan jenis kelamin, selaras dengan tuntutan sosial dan kultural masyarakat, (3) menerima keadaan fisik baik sebagai pria maupun wanita dan menggunakannya sesuai dengan kodratnya masing-masing, (4) menerima dan mencapai tingkah laku sosial tertentu yang bertanggung jawab di tengah-tengah masyarakat, (5) mencapai kebebasan emosional dari orang tua dan orang dewasa lainnya dan mulai menjadi diri sendiri, (6) mempersiapkan diri untuk mencapai karir tertentu dalam bidang kehidupan ekonomi, (7) mempersiapkan diri untuk memasuki dunia perkawinan dan kehidupan berkeluarga, dan (8) memperoleh seperangkat nilai dan sistem etika sebagai pedoman bertingkah laku dan mengembangkan ideologi untuk keperluan kehidupan kewarganegaraannya.

Berdasarkan tugas pada tahap perkembangan tersebut remaja seharusnya lebih banyak menghabiskan waktu untuk berinteraksi dengan kawan sebayanya, orang tua maupun guru. Namun pada kenyataannya fenomena pada saat ini dimana teknologi telah berkembang dengan pesat, remaja terlihat lebih banyak menghabiskan waktu dengan gadget yang dimilikinya baik berselancar di dunia maya maupun melakukan game online daripada berinteraksi secara langsung, malah terkesan apatis terhadap lingkungan sekitar. Perkembangan teknologi saat ini memungkinkan komunikasi digital tanpa tatap muka yang memberikan dampak tersendiri yang tidak selalu baik. Hal tersebut diperkuat oleh hasil survei yang dilakukan oleh Asosiasi Penyelenggara Jasa Internet Indonesia (APJII) yang menyatakan bahwa ada 171.17 juta pengguna internet indonesia di tahun 2018 yang didominasi oleh remaja. Hal ini tidak sesuai dengan tanda-tanda yang menandai minat sosial yakni persahabatan (friendship), cinta (love), kerja (work), dan self significance (Leak, 2011).

Sophie Wasson, psikolog di Harvard-Westlake menyebutkan potensi rasa terisolasi pada remaja memungkinkan remaja melewatkan kesempatan untuk mengembangkan hubungan emosional yang mendalam yang dibangun dengan komunikasi verbal dan nonverbal.

Hasil survei global PISA oleh Organisation for Economic Cooperation and Development (OECD) juga menunjukkan anak lebih sulit berteman dari tahun ke tahun. Hampir setiap negara yang melakukan survei ini mendapatkan hasil bahwa semakin sedikit remaja yang menganggap menjalin pertemanan adalah hal mudah. Hal ini menyebabkan remaja masa kini merasa kesepian.

Dari hasil observasi dan wawancara pada salah satu SMP di kota Malang dengan usia siswa 12-15 tahun dapat disimpulkan bahwa remaja melakukan interaksi dengan teman sebayanya seperlunya saja dimana remaja

\footnotetext{
${ }^{1}$ Universitas Muhammadiyah Malang

Korespondensi:

Hultia Manani Syarqi, Fakultas Psikologi, Universitas Muhammadiyah Malang

Email: hultiams@gmail.com
} 
tersebut kurang mengenal teman sebayanya hingga tidak mengetahui nama teman sekelasnya dan terkesan apatis ketika mengetahui temannya tidak masuk sekolah.

Banyak fenomena yang terjadi pada remaja masa kini yaitu lebih banyak menghabiskan waktu dengan teknologi dibandingkan berinteraksi dengan orang-orang sekitar yang seharusnya pada usia ini merupakan usia ideal dimana remaja mengalami proses belajar serta mengeksplorasi dan mengembangakan diri melalui lingkungan sekitar dan sosial untuk menumbuhkan minat sosial yang sudah ada dalam diri individu.

Minat sosial dalam gagasan yang dipaparkan Adler (Feist et al., 2017) adalah perasaan menyatu terhadap manusia yang dapat diartikan sebagai rasa keterlibatan diri dalam suatu kelompok yang memungkinkan individu untuk memiliki rasa empati terhadap anggota kelompok dan berorientasi untuk kepentingan bersama. Minat sosial juga dapat digunakan sebagai acuan atau barometer untuk mengetahui sehat atau tidaknya individu secara psikologis. Individu yang sehat secara psikologis adalah individu yang memiliki minat sosial yang tinggi, meletakkan kepentingan dan tujuan untuk keberhasilan bersama. Hal tersebut dapat diperkuat pula oleh hasil penelitian yang menyatakan bahwa minat sosial remaja dengan gangguan perilaku cenderung lebih rendah dibandingkan remaja yang normal.

Beberapa penelitian mengenai minat sosial memberikan hasil penelitian yang mengatakan bahwa minat sosial pada perempuan lebih tinggi dari laki-laki (Alizadeh et al., 2017). Penelitian lain juga menyebutkan bahwa orang tua menganggap minat sosial dalam organisasi sekolah dapat mempengaruhi konsep diri, empati, pandangan terhadap dunia dan perasaan tentang kewarganegaraan pada anak (West et al., 2018). Minat sosial dan tingkat pendidikan menunjukkan hubungan yang positif (Yuen, 2010), serta adanya perbedaan minat sosial antara usia dan jenis kelamin (Newbauer \& Stone, 2010).

Adanya beberapa hasil dari penelitian sebelumnya menyatakan seberapa pentingnya penelitian minat sosial. Individu yang memiliki minat sosial kurang cenderung mengarahkan perilaku ke arah negatif seperti menjadi delinquents, melakukan kejahatan, pecandu alkohol atau mental illness (Adler, 1997). Masalah tersebut memerlukan pemecahan masalah yang dapat membentuk perilaku yang bermanfaat bagi individu. Hal tersebut yang melatar belakangi peneliti untuk melakukan penelitian mengenai minat sosial pada remaja ditinjau dari latar belakang keluarga. Adapun mengapa ditinjau dari latar belakang keluarga dikarenakan mengembangkan minat sosial pada remaja membutuhkan peranan keluarga, khususnya orang tua. Latar belakang keluarga menurut Blishen et al. (1987) merupakan variabel-variabel yang dianalisis meliputi pendidikan ibu dan ayah serta status pekerjaan ibu dan ayah. Beberapa hasil penelitian tentang latar belakang keluarga yakni mengenai latar belakang status ekonomi orangtua menunjukkan bahwa hal tersebut mempengaruhi hasil kesehatan, kognitif, dan sosial emosional pada anakanak, dengan efek dimulai sebelum kelahiran dan berlanjut hingga dewasa (Bradley \& Corwyn, 2002). Seperti yang diketahui keluarga berfungsi sebagai sarana pembelajaran pertama dimana anak menjadikan orang tuanya sebagai role modelnya. Hal tersebut dilihat dari minat sosial bermula dari hubungan ibu dan anak, yang mana anak diasuh dari masa anak-anak hingga masa dewasa. Anak-anak yang telah melewati masa anak-anak telah engembangkan minat sosial yang ada pada awal masa perkembangan. Jadi bisa dikatakan minat sosial berkembang pada awal perkembangan namun pada usia remaja yang lebih berperan dalam minat sosial yakni lingkungan sosial. Hal ini dinyatakan bahwa lingkungan keluarga, lingkungan masyarakat, dan lingkungan sekolah yang mempengaruhi kepedulian sosial (Buchari, 2010).

Adanya beberapa hasil dari penelitian sebelumnya menyatakan pentingnya penelitian tentang minat sosial khususnya bagi remaja. Penelitian ini bertujuan untuk mengeksplorasi dan menganalisis minat sosial di kalangan remaja. Manfaat penelitian ini untuk mengetahui lebih jauh mengenai minat sosial di kalangan remaja baik sebab akibat maupun faktor-faktor yang mempengaruhinya.

\section{Tinjauan Pustaka}

\section{Minat Sosial}

Alfred Adler menjelaskan psikologi individual sebagai pandangan optimis akan manusia yang sangat bersandar pada gagasan minat sosial, yaitu perasaan menyatu dengan umat manusia. Menurut Adler (1997), manusia lahir dengan tubuh yang lemah dan inferior (suatu kondisi yang mengarah pada perasaan inferior, sehingga mengakibatkan ketergantungan terhadap orang lain). Oleh karena itu, perasaan menyatu dengan orang lain (minat sosial) sudah menjadi sifat manusia dan merupakan standar akhir untuk kesehatan psikologis (Adler, 1997).

Minat sosial adalah kebutuhan dasar setiap orang untuk hidup selaras dan bersahabat dengan orang lain. Selain itu, minat sosial juga adalah sebuah keinginan dalam diri individu yang berkonsentrasi pada tujuan untuk membentuk dan mengembangkan masyarakat yang ideal dimana sebagai bagian dari lingkungan, individu dan lingkungannya merupakan kesatuan yang utuh, yang saling melengkapi, memiliki relasi yang baik dan bersikap kooperatif untuk mengembangkan lingkungan ke arah yang lebih baik (Stoykova, 2013). Minat Sosial juga adalah sebuah minat dalam diri individu akan kesejahteraan orang lain, sehingga individu dengan minat sosial akan memiliki pemahaman dan rasa empati yang baik terhadap orang lain (Johnson \& Smith, 2011).

Berdasarkan beberapa definisi yang telah dinyatakan, minat sosial dapat disimpulkan sebagai rasa keterlibatan diri dalam suatu kelompok yang memungkinkan individu untuk memiliki rasa empati terhadap anggota kelompok lain dan berorientasi untuk kepentingan bersama.

Hal-hal yang menandai minat sosial yang dinyatakan Adler (Leak, 2011) yakni: (1) Persahabatan (Friendship) merupakan suatu bentuk hubungan yang terjalin dekat dan akrab antara individu satu dengan yang lain yang memungkinkan individu untuk menumbuhkan rasa saling peduli terhadap sesama, (2) Cinta (Love) merupakan suatu sikap yang diarahkan kepada orang lain yang dianggap istimewa, (3) Kerja (Work) yakni kepedulian dalam dunia kerja yang dapat mendorong individu bertanggung jawab terhadap tugas yang diberikan. Namun, tidak melupakan kerja sama kelompok untuk menciptakan lingkungan 
kerja yang nyaman, dan (4) Self significance merupakan keyakinan akan kemampuan dan penilaian diri terhadap diri sendiri dalam melakukan sebuah tugas atau menyelesaikan permasalahan, namun tidak mengabaikan pendapat orang lain.

Pengertian dari minat sosial atau bisa dikatakan social feeling adalah salah satu yang sangat penting. Penting untuk pendidikan, treatment, dan our cure. Hanya orang yang berani, self-confident yang bisa mendapatkan manfaat dan keuntungan dari masalah sosial yang dihadapi.

Anak-anak dengan tingkat minat sosial rendah tidak memiliki perilaku psikis untuk mengatasi masalah kehidupan yang dihadapi. Anak-anak yang merasa dikalahkan, mengembangkan sikap yang keliru terhadap masalah hidup. Anak-anak tersebut membutuhkan perawatan yang mendorong perilaku sosial positif atau berguna bagi kehidupan dan masyarakat.

Minat Sosial dikatakan sebagai barometer untuk mengetahui sehat atau tidaknya seorang individu secara psikis. Individu yang sehat secara psikologis adalah individu yang memiliki minat sosial yang tinggi, meletakkan kepentingan dan tujuan untuk keberhasilan bersama yang dimotivasi oleh perasaan bahwa manusia tidak sempurna namun dalam konteks yang wajar sehingga menghasilkan gaya hidup yang sehat. Adapun individu yang secara psikologis tidak sehat adalah individu yang memiliki minat sosial yang rendah dimotivasi oleh keuntungan pribadi sehingga meletakkan kepentingan dan tujuan untuk keberhasilan pribadi atau diri sendiri. Individu yang secara psikologis tidak sehat menumbuhkan pemikiran yang inferior dalam diri yang dilebihlebihkan yang menyebabkan gaya hidup kearah yang neurotis atau gangguan kejiwaan.

Kurangnya minat sosial cenderung mengarahkan individu ke arah negatif seperti menjadi delinquents, penjahat, pecandu alkohol, atau mental illness (Adler, 1997). Masalah tersebut memerlukan pemecahan masalah yang dapat membentuk perilaku yang bermanfaat bagi individu.

Minat sosial ada secara alamiah yang berasal dari potensi yang ada dalam diri individu, namun perlu dikembangkan. Minat sosial bermula dari hubungan ibu dan anak, yang mana anak diasuh dari masa anak-anak hingga masa dewasa. Anak-anak yang telah melewati masa anak-anak telah mengembangkan minat sosial yang ada pada awal masa perkembangan (Feist et al., 2017).

Adler (Feist et al., 2017) meyakini bahwa dampak dari lingkungan sosial pada tahun-tahun awal masa perkembangan anak yakni hubungan antara ayah dan anak maupun ibu dan anak sangat penting, sehingga dapat mengalahkan pengaruh dari keturunan. Adler (Feist et al., 2017) meyakini bahwa setelah anak berumur 5 tahun, efek dari keturunan akan dikaburkan oleh pengaruh kuat dari lingkungan sosial anak. Pengaruh lingkungan akan mengubah dan membentuk hampir setiap aspek kepribadian anak. Sehingga dapat dikatakan bahwa yang mempengaruhi minat sosial merupakan lingkungan sosial (Feist et al., 2017).

Adapun menurut Buchari (2010) lingkungan yang mempengaruhi kepedulian sosial terdiri dari : (a) Lingkungan Keluarga. Keluarga merupakan lingkungan sosial pertama yang akan dikenal oleh setiap manusia. Manusia belajar berinteraksi kepada orang lain untuk pertama kalinya dia pelajari dari lingkungan keluarga. Cara mengajar orang tua dirumah akan menumbuhkan kepedulian pada diri seorang anak. Sebagai contoh perilaku orang tua yang akan menumbuhkan kepedulian anak antara lain perilaku orang tua setiap hari dirumah maupun di lingkungan sekitar, perhatian yang diberikan orang tua terhadap anak, komentar orang tua di lingkungan sekitar dan bertindak terhadap lingkungan sekitarnya sangat mempengaruhi dalam perilaku kepedulian sosial seorang anak.; (b) Lingkungan Masyarakat. Lingkungan masyarakat ada dua tipe yang pertama perkotaan dan pedesaan. Dimana lingkungan sosial di pedesaan cenderung menanamkan sikap kepedulian sosial yang sangat erat. Dan gotong royong dan rasa kebersamaan sangat dijunjung tinggi dalam tradisi pedesaan. Situasi yang berbeda dialami pada lingkungan perkotaan yang dimana mereka cenderung bersikap individualisme dan jarang memperlihatkan perilaku kepedulian sosial antara warga. Beberapa hal yang menggambarkan lunturnya perilaku kepedulian sosial diantaranya yakni menjadi penonton saat terjadi musibah pada lingkungan atau tetangga kita dan hanya menjadi penonton, sikap acuh dan masa bodoh terhadap tetangga sekitar rumah, dan tidak ikut serta atau ambil andil dalam kegiatan yang ada di masyarakat; dan (c) Lingkungan Sekolah. Sekolah merupakan tempat bagi anak untuk berinteraksi terhadap sesama karena sekarang waktu anak dihabiskan di sekolah. Dan anak akan sering berinteraksi kepada guru, teman, dan pegawai yang ada di sekolah, sehingga lingkungan anak akan semakin luas dan kepedulian anak akan berkembang sesuai dengan lingkungan yang ada di sekolahnya. Ketika akan berinteraksi dengan teman yang memiliki kepedulian sosial maka anak tersebut akan ikut memiliki kepedulian terhadap orang lain. Namun, semua itu bisa saja terjadi sebaliknya ketika mereka memiliki teman yang tidak mempunyai kepedulian maka anak tersebut akan ikut acuh terhadap lingkungan dan acuh terhadap apa yang terjadi pada orang lain. Sikap peduli di lingkungan sekolah dapat ditunjukkan dengan perilaku saling membantu, menyapa, berbagi senyum dan salam antar warga sekolah.

\section{Minat Sosial dan Latar Belakang Keluarga}

Minat sosial merupakan rasa keterlibatan diri dalam suatu kelompok yang memungkinkan individu untuk memiliki rasa empati terhadap anggota kelompok lain dan berorientasi untuk kepentingan bersama. Minat sosial ada secara alamiah berasal dari potensi yang ada dalam diri individu, namun perlu dikembangkan. Dalam hal ini keluargalah yang pertamakali mengenalkan mengenai minat sosial. Keluarga sendiri terdiri dari ayah, ibu, dan anak. Keluarga juga merupakan unit sosial ekonomi terkecil dalam masyarakat. Adapun latar belakang keluarga yang dinyatakan oleh Blishen et al. (1987) merupakan variabel-variabel yang dianalisis meliputi pendidikan ibu dan ayah maupun status kerja ibu dan ayah. Penelitian Bradley \& Corwyn (2002) menyatakan bahwa latar belakang keluarga dapat mempengaruhi kesehatan, kognitif, dan sosial-emosional pada anak-anak, dengan efek yang dimulai sebelum kelahiran dan berlanjut hingga dewasa.

Friedman (2010) menyatakan fungsi keluarga sebagai: (a) Fungsi afektif dan koping. Keluarga memberikan kenyamanan emosional, membantu dalam membentuk identitas dan mempertahankan saat terjadi stres; (b) Fungsi sosialisasi. Keluarga sebagai guru, menanamkan kepercayaan, nilai, 
sikap, memberikan feedback, dan memberikan petunjuk dalam pemecahan masalah; (c) Fungsi reproduksi. Keluarga melahirkan anak, menumbuh kembangkan anak, dan meneruskan keturunan; (d) Fungsi ekonomi. Keluarga memberikan finansial untuk anggota keluarganya dan kepentingan di masyarakat; dan (e) Fungsi fisik. Keluarga memberikan keamanan, kenyamanan lingkungan yang dibutuhkan untuk pertumbuhan, perkembangan dan istirahat termasuk penyembuhan dari rumah sakit

Fungsi yang dinyatakan Friedman (2010) mengenai latar belakang keluarga memiliki peranan sangat penting khususnya fungsi ekonomi. Hasil penelitian menyatakan bahwa SES (Sosial Ekonomi Status) orang tua memiliki efek pada kesejahteraan orang dewasa awal dan kesejahteraan dan perilaku kesehatan selain yang dimediasi oleh SES (Huurre et al., 2003), latar belakang pendidikan dan sosial ekonomi orang tua mempengaruhi pendidikan anak-anak (Kainuwa \& Yusuf, 2013), dan ada juga penelitian yang menyatakan Status sosial ekonomi orang tua dan latar belakang pendidikan orang tua tidak memiliki pengaruh signifikan terhadap kinerja akademik siswa. Namun, kualifikasi pendidikan orang tua dan status kesehatan siswa diidentifikasi untuk memiliki pengaruh signifikan secara statistik terhadap kinerja akademik siswa. Dua variabel yang menunjukkan pengaruh signifikan mencerminkan sifat lingkungan rumah siswa dan memainkan peran penting dalam prestasi akademik responden (Ogunshola \& Adewale, 2012).

Berdasarkan pernyataan yang telah dipaparkan, penulis melakukan penelitian mengenai minat sosial dan latar belakang keluarga untuk mengetahui dan mengeksplorasi minat sosial yang ditinjau berdasarkan faktor demografis khususnya terkait dengan latar belakang keluarga. Latar belakang keluarga yakni merupakan variabel-variabel yang dianalisis meliputi pendidikan ibu dan ayah serta status pekerjaan ibu dan ayah (Blishen et al., 1987). Apakah hal tersebut memiliki pengaruh, dampak, atau perbedaan pada minat sosial Seperti yang telah diketahui minat sosial dikatakan sebagai barometer untuk mengetahui kesehatan mental seorang individu secara psikis. Kurangnya minat sosial cenderung mengarahkan individu ke arah negatif seperti menjadi delinquents, penjahat, pencandu alkohol atau mental illness (Adler, 1997).

\section{Metode}

\section{Desain Penelitian}

Penelitian ini menggunakan studi deskriptif kuantitatif dan kualitatif yang sering dikatakan sebagai pendekatan campuran. Pendekatan kuantitatif perolehan datanya berupa angka atau kuantitatif melalui pengolahan data statistik sedangkan pendekatan kualitatif perolehan datanya berupa deskriptif. Adapun desain penelitian yang digunakan yakni eksplanatoris sekuensial yang didahului dengan pengumpulan dan analisis data kuantitatif, kemudian diikuti oleh pengumpulan dan analisis data kualitatif (Putra \& Hendarman, 2013). Pendekatan campuran ini bertujuan untuk memperoleh data melalui statistik yang kemudian diperdalam lagi dengan penjelasan deskriptif.

\section{Subjek Penelitian}

Subjek pada penelitian ini adalah remaja usia 12-18 tahun, dengan jumlah 196 subjek. Adapun teknik yang digunakan dalam penelitian ini adalah haphazard sampling, yaitu satuan sampling dipilih seadanya tanpa perhitungan apapun tentang derajat kerepresentatifannya (Arrens \& Loebbecke, 2000).

\section{Variabel dan Instrumen Penelitian}

Minat sosial diukur menggunakan Social Interest Index (SII) dari Leak (2011) yang terdiri dari empat aspek yakni friendship, self significance, love, dan work berisi 32 item. SII dibuat dalam bentuk skala likert dengan lima pilihan jawaban yang sesuai atau menyerupai keadaan subjek penelitian yakni sangat setuju (SS) diberikan skor 5, setuju (S) diberikan skor 4, netral (N) diberikan skor 3, tidak setuju (TS) diberikan skor 2, dan sangat tidak setuju (STS) diberikan skor 1. Salah satu contoh pernyataannya yakni "saya memiliki banyak teman", maka subjek memberi pilihan jawaban dengan memberikan skor 1 (STS) hingga 5 (SS). Rentangan skor SII yang diperoleh subjek berada diantara 32 hingga 160, skor tinggi menunjukkan minat sosial individu yang tinggi, dan sebaliknya skor rendah menunjukkan minat sosial individu yang rendah. Adapun hasil uji reliabilitas Social Interest Index diperoleh Alpha sebesar sebesar 0,90 pada saat pengambilan data penelitian.

\section{Analisis Data}

Prosedur penelitian terdiri dari tiga tahap yakni tahap persiapan, pelaksanaan, dan analisa data. Pada tahap pertama yakni persiapan, peneliti mempersiapkan materi yang sesuai dengan kajian teoritik penelitian yang akan dilakukan. Peneliti juga mempersiapkan alat ukur penelitian yang sudah diterjemahkan ke dalam bahasa Indonesia dan dimodifikasi bahasanya agar mudah dipahami subjek penelitian namun tidak mempengaruhi makna yang ada sebelumnya untuk diujicobakan. Uji coba alat ukur dilakukan kepada 80 orang dengan kriteria subjek yakni merupakan siswa siswi SMP di salah satu kota Malang, duduk di kelas 7 atau 8 SMP, dan berusia antara 12-15 tahun. Setelah pengambilan data peneliti melakukan analisa data menggunakan aplikasi SPSS untuk mengetahui data valid atau tidaknya serta mengetahui reliabilitasnya.

Pada tahap kedua yakni pelaksanaan, peneliti menyebarkan skala pada subjek yang memenuhi kriteria yang telah ditetapkan dalam penelitian tersebut. Pemberian skala dilakukan kepada 80 subjek penelitian. Pada tahap ketiga yang merupakan tahap terakhir yakni analisis data. Peneliti menganalisis data yang telah didapatkan dari hasil penyebaran skala. Hasil skala yang diperoleh dianalisis menggunakan program aplikasi SPSS.

\section{Hasil dan Diskusi}

\section{Data Demografis}

Subjek penelitian terdiri dari 112 perempuan (57.1\%) dan 84 laki-laki $(42.9 \%)$ yang sedang menempuh pendidikan Sekolah Menengah Pertama dan Sekolah Menengah Atas. Urutan kelahiran subjek penelitian terdiri dari dari 82 anak sulung (41.8\%), 27 anak tengah (13.8\%), 67 anak bungsu (34.2\%), dan 20 anak tunggal (10.2\%) dengan status 
keluarga terdapat 77 anak (39.3\%) dengan keadaan orang tua yang sudah bercerai.

\section{Hasil Kuantitatif}

Minat sosial Subjek Secara Umum Berdasarkan penelitian yang telah dilakukan menggunakan SII pada 196 subjek diperoleh hasil minimum 32, maksimum 156, dengan ratarata 119.63 serta standar deviasi 16.29 pada hasil minat sosial. Adapun hasil kategorisasi minat sosial pada remaja didapatkan 22 remaja (11.2\%) yang memiliki minat sosial rendah, 146 remaja $(74.5 \%)$ memiliki minat sosial sedang, dan 28 remaja memiliki minat sosial tinggi (14.3\%).

Minat sosial Berdasarkan Karakteristik Subjek Deskripsi hasil penelitian yang telah dilakukan berdasarkan karakteristik subjek yakni jenis kelamin, usia, serta urutan kelahiran dijelaskan sebagai berikut.

Berdasarkan jenis kelamin terdapat 112 perempuan $(57.1 \%)$ dengan nilai rata-rata $120.34(\mathrm{SD}=15.38)$ dan 84 laki-laki $(42.9 \%)$ dengan nilai rata-rata $118.68(\mathrm{SD}=17.48)$. Subjek perempuan yang termasuk dalam kategori minat sosial rendah sebanyak 10 subjek, sedang 88 subjek, dan tinggi sebanyak 14 subjek, sedangkan untuk subjek laki-laki terdapat 12 subjek dalam kategori rendah, 58 sedang, dan 14 subjek dengan kategori tinggi.

Berdasarkan usia yakni dimulai dari usia 12-18 tahun diklasifikasikan dalam tahap perkembangan remaja dengan jumlah 196 subjek serta rata-rata 13.88 (SD = 1.36). Remaja dengan kategori minat sosial tinggi sebanyak 28 subjek, kategori sedang sebanyak 146 subjek, dan kategori rendah sebanyak 22 subjek. Adapun berdasarkan urutan kelahiran diklasifikasikan menjadi 4 yakni anak sulung, tengah, bungsu, serta tunggal dengan nilai rata-rata sebesar 2.13 (SD $=1.08$ ). Anak sulung yang dikategorikan dengan minat sosial tinggi sebanyak 14 subjek, sedang 58 subjek, dan kategori rendah 10 subjek. Anak tengah yang dikategorikan dengan minat sosial tinggi sebanyak 3 subjek, sedang 20 subjek, dan kategori rendah 4 subjek. Anak bungsu yang dikategorikan dengan minat sosial tinggi sebanyak 5 subjek, sedang 53 subjek, dan kategori rendah 9 subjek dan anak tunggal yang dikategorikan dengan minat sosial tinggi sebanyak 2 subjek, sedang 15 subjek, dan kategori rendah 3 subjek.

Menurut penjelasan di atas dapat disimpulkan bahwa minat sosial berdasarkan karakteristik subjek berada pada kategori sedang. Adapun hasil dari uji korelasi maupun uji beda didapatkan nilai sig $>0.05$ yang berarti tidak ada hubungan ataupun perbedaan signifikan terhadap karakteristik subjek.

Minat sosial berdasarkan latar belakang keluarga Pada penelitian yang telah dilakukan dapat dipaparkan minat sosial remaja ditinjau berdasarkan latar belakang keluarga yakni sebagai berikut.

Status keluarga diklasifikasikan menjadi dua yakni bercerai dan tidak bercerai, dengan jumlah keluarga yang bercerai sebanyak 77 (39.3\%) dan sisanya sebanyak 119 $(60,7 \%)$ dengan keluarga yang utuh, nilai rata-rata sebesar 1.39 (SD = 0.49). Remaja dengan status keluarga bercerai yang termasuk dalam kategori minat sosial rendah sebanyak 10 subjek, sedang 53 subjek, dan tinggi sebanyak 14 subjek, sedangkan untuk remaja dengan status keluarga yang utuh
Tabel 1. Uji Beda dan Uji Korelasi

\begin{tabular}{ll}
\hline Karakteristik Subjek & Sig. \\
\hline Jenis Kelamin & 0.406 \\
Usia & 0.774 \\
Urutan Kelahiran & 0.602 \\
Latar Belakang Keluarga & \\
$\quad$ Status Keluarga & 0.816 \\
Pendidikan Terakhir Ayah & 0.474 \\
Pendidikan Terakhir Ibu & 0.616 \\
Pekerjaan Ayah & 0.848 \\
Pekerjaan Ibu & 0.138 \\
\hline
\end{tabular}

terdapat 12 subjek dalam kategori rendah, 93 subjek kategori sedang, dan 14 subjek dengan kategori tinggi.

Adapun deskripsi subjek berdasarkan pendidikan terakhir orang tua yakni ayah dan ibu diklasifikasikan menjadi 4 yaitu SD, SMP, SMA, dan Perguruan Tinggi. Pendidikan terakhir Ayah memperoleh nilai rata-rata sebesar $2.65(\mathrm{SD}=0.93)$ sedangkan pendidikan terakhir ibu nilai rata-rata sebesar 2.56 ( $\mathrm{SD}=0.93$ ). Pada pendidikan terakhir ayah di tingkat SD sebanyak 29, SMP sebanyak 43, SMA sebanyak 91, dan di tingkat perguruan tinggi sebanyak 33, sedangkan untuk pendidikan terakhir Ibu di tingkat SD sebanyak 32, SMP sebanyak 51, SMA sebanyak 85, dan di tingkat perguruan tinggi sebanyak 28 .

Selanjutnya berdasarkan pekerjaan orang tua baik ayah dan ibu dijelaskan sebagai berikut. Sebanyak 11 (5.6\%) ayah bekerja sebagai PNS, $4(2.0 \%)$ ayah bekerja sebagai tentara, $95(48.5 \%)$ ayah bekerja sebagai wirausaha, 43 (21.9\%) ayah bekerja sebagai karyawan, dan pekerjaan lainnya sebanyak 43 (21.9\%) dengan nilai rata-rata 3.53 (SD $=1.03)$. Sedangkan pekerjaan ibu didapatkan hasil sebanyak $8(4.1 \%)$ ibu bekerja sebagai PNS, 120 (61.2\%) ibu bekerja sebagai IRT, 33 (16.8\%) ibu bekerja sebagai wirausaha, 21 $(10.7 \%)$ ibu bekerja sebagai karyawan, dan pekerjaan ibu lainnya sebanyak $14(7.1 \%)$ dengan nilai rata-rata 2.56 (SD $=0.99$ ).

Menurut hasil pemaparan di atas dapat disimpulkan bahwa minat sosial berdasarkan latar belakang keluarga berada pada kategori sedang. Adapun hasil dari uji korelasi maupun uji beda didapatkan nilai sig $>0.05$ yang berarti tidak ada hubungan ataupun perbedaan signifikan terhadap latar belakang keluarga. Hal ini dapat dilihat pada tabel 1 .

\section{Hasil Kualitatif}

Data kualitatif didapat dari hasil wawancara pada lima subjek penelitian yang termasuk dalam 196 subjek sebelumnya. Wawancara dilakukan selama kurang lebih enam bulan melalui panduan minat sosial dalam empat tema yakni persahabatan (friendship), cinta (love), kerja (work), dan self significance.

Persahabatan. Berdasarkan hasil wawancara yang telah dilakukan dapat disimpulkan bahwa aspek persahabatan pada remaja terpenuhi hal ini dinyatakan dalam pernyataan:

"Punya. saya punya teman dekat biasanya dia sering curhat ke saya walaupun saya gak curhat ke dia. Soalnya saya gak seneng curhat sih hehehe". 
Dalam pernyataan tersebut dapat dikatakan bahwa subjek memiliki hubungan yang terjalin dekat dan akrab antara individu satu dengan yang lain, dalam hal ini subjek mau mendengarkan keluh kesah teman dekatnya yang memungkinkan subjek untuk menumbuhkan rasa saling peduli terhadap sesama.

Cinta. Berdasarkan hasil wawancara didapatkan hasil bahwa pada aspek cinta terpenuhi hal ini dinyatakan dalam pernyataan:

"Punya. kadang kalo pacar saya punya tugas saya bantu mengerjakan".

Pernyataan tersebut menunjukkan bahwa aspek cinta terpenuhi dimana individu membentuk suatu sikap kepada orang lain yang dianggap istimewa yang pada hal ini ditunjukkan dengan membantu dalam mengerjakan tugas.

Kerja. Berdasarkan hasil wawancara dapat dikatakan bahwa aspek kerja pada subjek kurang memadai hal ini dibuktikan dalam pernyataan subjek:

"Ya gak ngerjain";"paling cuma ngerjain bagian saya aja".

Pada dua pernyataan tersebut menunjukkan kurangnya rasa kepedulian terhadap tugas yang diberikan yang menyebabkan subjek kurang bertanggung jawab. Seharusnya kerja kelompok memungkinkan subjek untuk menciptakan lingkungan kerja kelompok yang nyaman namun pada kenyataannya yang terjadi adalah sebaliknya.

Self Significance. Berdasarkan hasil wawancara yang telah dilakukan, dapat disimpulkan bahwa kemampuan penilaian terhadap diri sendiri terhadap tugas tanpa mengabaikan pendapat orang lain atau bisa disebut dengan self significance cukup bagus, dimana subjek cukup mampu menilai diri sendiri dalam menyelesaikan tugas sekolah, berikut pernyataan subjek:

"Kalo saya punya tugas sekolah terus gak bisa saya kerjakan saya biasanya nanya ke teman yang bisa, kalo bisa ngerjain sendiri ya saya kerjakan sendiri"

Dari pernyataan tersebut dapat disimpulkan bahwa subjek memiliki self significance yang bagus dimana subjek paham akan kemampuan dirinya sehingga apabila subjek merasa tidak bisa ia akan bertanya kepada temannya yang dirasa mampu untuk membantunya dalam mengerjakan tugas.

\section{Diskusi}

Hasil penelitian ditinjau dari penelitian sebelumnya yakni mengenai minat sosial berdasarkan karakteristik subjek yakni jenis kelamin, usia, dan urutan kelahiran dimana hasil penelitian pada jurnal sebelumnya menunjukkan bahwa minat sosial pada perempuan lebih besar dari laki-laki (Saunders \& Roy, 1999), urutan kelahiran psikologis anak bungsu dan tengah saling berhubungan dengan minat sosial (Tekinalp \& Terzi, 2014), dan ada juga hasil penelitian yang menunjukkan bahwa terdapat perbedaan antara usia dan jenis kelamin terhadap minat sosial (Newbauer \& Stone, 2010).
Namun, pada penelitian ini didapatkan hasil bahwa tidak ada perbedaan ataupun hubungan mengenai minat sosial dengan karakteristik subjek. Jadi, dapat disimpulkan pada hasil penelitian ini bahwa jenis kelamin, usia, maupun urutan kelahiran tidak banyak mempengaruhi minat sosial pada remaja.

Adapun hasil penelitian mengenai minat sosial berdasarkan latar belakang keluarga yakni status keluarga, tingkat pendidikan, serta pekerjaan menunjukkan bahwa tidak ada perbedaan ataupun hubungan. Hal ini tidak sesuai dengan jurnal sebelumnya yang menyatakan bahwa terdapat hubungan positif antara minat sosial dan pendidikan (Yuen, 2010). Berdasarkan uraian di atas dapat disimpulkan bahwa terdapat perbedaan antara hasil penelitian dengan hasil penelitian sebelumnya. Hal ini disebabkan oleh berbagai faktor baik itu kriteria partisipan yang berbeda, wilayah atau tempat dilakukan penelitian, ada juga perbedaan generasi pada subjek penelitian di setiap penelitian dimana hal tersebut dapat mempengaruhi hasil penelitian yang dilakukan.

Hasil Penelitian dengan Teori minat sosial Teori minat sosial dikemukakan oleh Adler yang menyatakan bahwa minat sosial adalah individu yang aktif dalam kelompok. Adler juga menyatakan hal-hal yang menandai social interest yakni aspek persahabatan (friendship), cinta (love), kerja (work), dan self significance.Pada keempat aspek partisipan kebanyakan memiliki minat sosial rendah pada aspek kerja dimana individu diminta untuk bertanggung jawab tugas yang diberikan namun, tidak melupakan kerjasama kelompok untuk menciptakan lingkungan kerja yang nyaman. Pada hal ini kebanyakan partisipan belum mampu menciptakan lingkungan kerja kelompok yang nyaman sehingga menyebabkan tugas yang tidak terselesaikan yang menunjukkan kurangnya tanggung jawab kelompok dalam menyelesaikan hal tersebut. Adapun pada aspek yang lain sudah terpenuhi hal ini ditunjukkan dalam pernyataan yang dinyatakan partisipan dalam wawancara yang telah dilakukan.

Adapun menurut Buchari (2010) lingkungan yang mempengaruhi minat sosial yakni lingkungan keluarga, masyarakat, dan sekolah. Dalam hal ini peneliti lebih menekankan pada latar belakang keluarga setiap partisipan, dimana partisipan yang memiliki minat sosial rendah kebanyakan memiliki latar belakang keluarga yang bercerai, sosial ekonomi yang rendah maupun kurangnya tingkat pendidikan orang tua. Walaupun ada juga partisipan yang memiliki latar belakang tersebut memiliki minat sosial yang cukup hal ini disebabkan oleh faktor lingkungan dalam pembentukan karakter setiap individu yang memungkinkan individu memiliki tingkatan minat sosial yang lebih tinggi dari yang seharusnya. Hal ini ditunjukkan dengan hasil penyebaran skala minat sosial yang menunjukkan bahwa tingkatan minat sosial pada remaja terpenuhi atau bisa dikatakan cukup.

Deskripsi Tingkat minat sosial Minat sosial dibagi menjadi 3 tingkatan yakni dikategorisasikan menjadi tinggi, sedang, dan juga rendah. Kategorisasi ini dihitung berdasarkan skor populasi subjek terdistribusi secara normal (Azwar, 2017). Berdasarkan hasil penelitian yang dilakukan, tingkatan minat sosial pada penelitian ini dapat dikategorisasikan 
memasuki posisi sedang, walaupun ada juga sebagian kecil yang memiliki tingkatan minat sosial rendah, dan ada juga yang tinggi. Hal ini dikarenakan adanya beberapa faktor penyebab baik itu faktor lingkungan maupun faktor keluarga yang dalam hal ini dikatakan sebagai latar belakang keluarga. Sejalan dengan hasil penelitian Bradley \& Corwyn (2002) menyatakan bahwa latar belakang keluarga dapat mempengaruhi kesehatan, kognitif, dan sosial-emosional pada anak-anak, dengan efek yang dimulai sebelum kelahiran dan berlanjut hingga dewasa.

Pada penelitian ini peneliti lebih menekankan pada faktor latar belakang keluarga setiap individu yang berpartisipasi pada penelitian. Seperti yang dikatakan Friedman (2010) dalam bukunya mengenai fungsi keluarga yakni fungsi afektif, sosialisasi, reproduksi, ekonomi, maupun fungsi fisik mempengaruhi tingkatan minat sosial partisipan. Partisipan yang memiliki tingkatan minat sosial tinggi biasanya merupakan anak-anak yang memiliki latar belakang keluarga yang baik dalam hal ini memiliki keluarga yang harmonis serta lingkungan yang mendukung perkembangan anak. Adapun partisipan yang memiliki tingkatan minat sosial rendah kebanyakan memiliki latar belakang keluarga dengan status keluarga yang bercerai. Namun, tidak semua partisipan yang memiliki latar belakang keluarga dengan status bercerai memiliki tingkatan minat sosial rendah dikarenakan adanya faktor pendukung lain yang menyebabkan tingkatan minat sosial mencukupi yang dalam hal ini adalah faktor lingkungan dimana baik faktor keluarga saling berkaitan dengan lingkungan dan tidak dapat terpisah dengan hal tersebut yang dalam hal ini menjadi faktor penentu dimana kebanyakan partisipan memiliki tingkatan minat sosial sedang. Walaupun keluarga partisipan tidak harmoni namun dengan bantuan teman maupun guru dapat membentuk partisipan menjadi pribadi yang baik yang dalam hal ini adalah minat sosial yang dimiliki setiap individu.

\section{Penutup}

\section{Kesimpulan}

Berdasarkan penelitian yang dilakukan dapat disimpulkan secara umum bahwa tingkatan minat sosial pada remaja ditinjau dari latar belakang keluarga dapat dikategorikan kedalam kategori sedang atau cukup. Analisa dalam penelitian ini juga menunjukkan bahwa tidak ada perbedaan ataupun korelasi yang signifikan antara minat sosial dengan kriteria subjek maupun latar belakang keluarga.

\section{Implikasi}

Dengan adanya penelitian ini penulis berharap bahwa informasi-informasi yang dipaparkan mengenai minat sosial pada remaja ditinjau dari latar belakang keluarga dapat menambah wawasan pendidik dalam memahami siswa di kelas. Khusus bagi orang tua diharapkan dengan adanya penelitian ini selain dapat memahami bagaimana minat sosial pada anaknya yang sudah beranjak remaja juga dapat mengetahui hal apa yang sekiranya dapat dilakukan untuk membantu perkembangan remaja dalam meningkatkan minat sosial. Adapun saran yang diberikan penulis bagi peneliti selanjutnya dengan topik yang serupa yakni item pertanyaan yang diberikan kepada subjek penelitian sebaiknya tidak terlalu banyak, selain menggunakan expert judgement perlu melakukan uji coba terlebih dahulu kepada subjek yang serupa disertai dengan pengisian feedback oleh partisipan agar penulis mengetahui apakah bahasa yang digunakan dalam skala mudah dipahami atau tidak, dikarenakan masih banyak subjek yang merasa bahasa yang digunakan terlalu tinggi walaupun sudah melakukan expert judgement dan uji coba alat ukur.

\section{Referensi}

Adler, A. (1997). Undertanding life. Holland: Oneworld Publication.

Alizadeh, H., Ferguson, E. D., Murphy, J. M., \& Soheili, F. (2017). Development of the social interest scale for iranian children aged 4-12 a qualitative model of knowledge, skills, and attitudes supporting adlerian-based trauma psychotherapy. The Journal of Individual Psychology, 73(1), 38-53. doi:10.1353/jip.2017.0003

Arrens, A.A., \& Loebbecke, J.K. (2000). Auditing: An integrated approach. New Jersy: Prentice Hall International Inc.

Azwar, S. (2017). Metode penelitian psikologi. Yogyakarta: Pustaka Pelajar.

Blishen, B. R., Carrol, W. K., \& Moore, C. (1987). The 1981 socioeconomic index for occupations in Canada. Canadian Review of Sociology and Anthropology, 24(4), 465-488. https://doi.org/10.1111/j.1755-618X.1987.tb00639.x

Bradley, R. H., \& Corwyn, R.F. (2002). Socioeconomic status and child development. Annual review of psychology, 53, 371-399. https://doi.org/10.1146/annurev.psych.53.100901.135233

Buchari, A. (2010). Pembelajaran studi sosial. Bandung: Alfabeta.

Feist, J., Feist, G. J., \& Roberts, D. T. A. (2017). Teori kepribadian. Jakarta: Salemba Humanika.

Friedman, M. (2010). Buku ajar keperawatan keluarga : Riset, teori, dan praktek. Edisi ke-5. Jakarta: EGC.

Hurlock, E. B. (2012). Psikologi perkembangan, suatu pendekatan sepanjang rentang kehidupan (terjemahan). Jakarta: Erlangga.

Huurre, T., Aro, H., \& Rahkone, O. (2003). Well-being and health behaviour by parental socioeconomic status: A follow-up study of adolescents aged 16 until age 32 years. Soc Psychiatry Psychiatr Epidemiol, 35(8), 249-255. doi: 10.1007/s00127003-0630-7.

Johnson, P. \& Smith, A. J. (2011). Social interest and differentiation of self.proffesional issues in counseling. Diunduh dari http://www.shsu.edu/piic/SocialInterestandDifferentiationofSelf.htm

Kainuwa, A., \& Yusuf, N.B.M. (2013). Influence of socio-economic and educational background of parents on their children's education in nigeria. International Journal Of Scientific And Research Publications, 3(10), 1-8.

Leak, G. K. (2011). Confirmatory factor analysis of the social interest index. SAGE Open.

Newbauer, J. F., \& Stone, M. H. (2010). Social interest and selfreported distress in a delinquent sample: Application of the sssi and the maysi-2. Journal of Individual Psychology, 66(2), 201215.

Ogunshola, F., \& Adewale, D. A. (2012). The effects of parental socio-economic status on academic performance of students in selected schools in edu lga of kwara state nigeria. International Journal of Academic Research in Business and Social Sciences, 2(7), 230-239. 
Putra, N., \& Hendarman. (2013). Metode riset campur sari. Jakarta: Indeks.

Santrock, J.W. (2012). Life-span development. Edisi 13. Jilid 1. Jakarta: Erlangga.

Saunders, S. A., \& Roy, C. (1999). The relationship between depression, satisfaction with life, and social interest. Sourt Pacific Journal of Psychology, 11(1), 9-15. doi:10.1017/S0257543400000717

Stoykova, Zh. (2013). Social interest and motivation. Trakia Journal of Science, 11(3), 286-290.
Tekinalp, B. E., \& Terzi, Ş. (2014). Coping, social interest, and psychological birth order as predictors of resilience in turkey. Applied Research Quality Life, 11(2), 509-524. doi:10.1007/S11482-014-9378-3

West, E.M., Miller, L.G., Cox, J.A., \& Moate, R.M. (2018). Parents' perceptions of young children's social interest experiences. The Journal of Individual Psychology, 74(4), 368-386.

Yuen, T. (2010). Counseling with adolescents in hong kong : An effective groupwork revisited. Procedia Social and Behavioral Sciences, 5, 2047-2057. doi:10.1016/j.sbspro.2010.07.411 